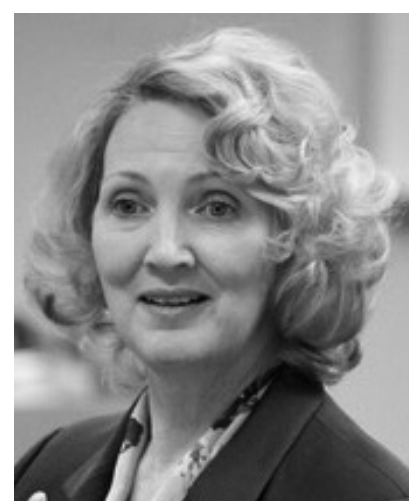

\section{Teresa Stanton Collett}

Professor of Law, University of St. Thomas School of Law, Minneapolis, MN, USA. Among the courses she teaches, Professor Collett teaches bioethics, Catholic Social Thought and the United Nations, and human sexuality and the law. She is an elected member of the American Law Institute, and has testified before committees of the U.S. Senate and House of Representatives, as well as before legislative committees in several states, on issues regarding the definition and responsibilities of marriage, parental rights, and government authority over medical decision making by minors.

In 2009, Pope Benedict XVI appointed Collett to a five-year term on the Pontifical Council for the Family. His Holiness Pope Francis renewed her appointment until 2016 when the Diacastery for the Laity, Family and Life assumed the responsibilities of the Council. In 2013, she served as a delegate to the International Conference on Population and Development (ICPD) for the Mission of the Holy See to the United Nations

tscollett@stthomas.edu

Teresa Stanton Collett

\title{
A Troubling Trio of Family Law Issues: Contributions from Comparative Law
}

\author{
https://doi.org/10.32082/fp.v3i53.307
}

Marriage, Children, and Family: Modern Challenges and Comparative Law Perspective ${ }^{1}$ is a timely collection of essays commissioned by the Center for Family Research at the Nicolaus Copernicus University in Torun (Poland) as well as part of the work of the Institute of Justice of Warsaw. The authors, all experts with international reputations for their contributions to family law development, explore three discrete topics: the nature of marriage, sexualization of children, and involuntary commitment for addiction. While not obvious at first, these topics relate deeply to each other and to public policies promoting a healthy civil society.

Marriage has long been understood to be the foundation for creation of healthy families, and

1 G. Blicharz (red.), Marriage, Children, and Family: Modern Challenges and Comparative Law Perspective, Wydawnictwo Instytutu Wymiaru Sprawiedliwości, Warszawa 2019. family is "the natural and fundamental group unit of society." Virtually all societies throughout history have recognized marriage as the social structure in which childbearing is both approved and expected. ${ }^{3}$ When marriage falters,

2 Universal Declaration of Human Rights, Art. 16 (1948). See also Pontifical Council for Justice and Peace, The Compendium of the Social Teaching of the Church, $\$ 211$ (2004) ("The family, in fact, is born of the intimate communion of life and love founded on the marriage between one man and one woman. It possesses its own specific and original social dimension, in that it is the principal place of interpersonal relationships, the first and vital cell of society."), and Constitution of RP, Chapter I „Rzeczypospolita” art. 18, 1997.

3 S. Girgis, R. T. Anderson, R. P. George, What is Marriage? Man and Woman: A Defense, Encounter Books, 2012, p. 38.; J. Corvino, M. Gallagher, Debating Same Sex Marriage, Oxford University Press, Oxford 2012, p. 96; A. Wax, The Family Law Doctrine of 
family formation is stymied or warped. ${ }^{4}$ When marriages fail to form (or fail after being formed), children often lose the protection of their biological parents and become more vulnerable to sexual assault ${ }^{5}$ and premature sexual debut. ${ }^{6}$ The plague of substance abuse and addiction is but one cause of such failure, and can destroy the family ${ }^{7}$ or threaten grave harm to its members. ${ }^{8}$

Marriage, Children, and Family is rich in addressing these issues. Foreign authors provide clear and read-

\section{The authors explore three discrete topics:} the nature of marriage, sexualization of children,
and involuntary commitment for addiction.

Equivalence, „Michigan Law Review” 2009, vol. 107, issue 6, pp. 999-1017.

4 D. Svyrydenko, D. Tułowiecki, Family Policy of the State as a Response to Social Security Threats, „Future Human Image” 2018, vol. 10, pp. 92-102, https://www.ceeol.com/search/ article-detail?id=730295; M. Such-Pyrgiel, Legal Changes Against the Family and Single People in Twenty First Century in Poland, „Annales Univeristatis Apulensis. Series Jurisprudentia” 2014, vol. 17, pp. 148-156, https://www.researchgate. net/publication/328956687_LEGAL_CHANGES_AGAINST_ THE_FAMILY_AND_SINGLE_PEOPLE_IN_TWENTY_ FIRST_CENTURY_IN_POLAND; A. Å. Kastbom, G. Sydsjö, M. Bladh, G. Priebe, C. G. Svedin, Differences in sexual behavior, health, and history of child abuse among students who had and had not engaged in sexual activity by the age of 18 years: a cross sectional study, ,Adolescent Health, Medicine and Therapeutics 2016, vol. 7, pp. 1-11.

5 "Compared to the control group, the girls with suicidal behaviors and the girls with violent behaviors were more likely to come from reconstructed families (pseudo-R2 Nagelkerke $=0.21 ; \mathrm{p}=0.00$ ) and to have experienced divorce/separation of their parents (pseudo-R2 Nagelkerke $=0.06 ; \mathrm{p}<0.05$ ) or consequent absence - physical and/or emotional, of the biological father (pseudo-R2 Nagelkerke $=0.06$; p $<0.05$ ).", K. Sitnik-Warchulska, B. Izydorczyk, Family Patterns and Suicidal and Violent Behavior among Adolescent Girls - Genogram Analysis, „International Journal of Environmental Research and Public Health" 2018, vol. 15, issue 9, pp. 1-16.

6 A. A. Kastbom, G. Sydsjö, M. Bladh, G. Priebe, C. G. Svedin, Differences in sexual behavior..., pp. 1-16; A. Å. Kastbom, G. Sydsjö, M. Bladh, G. Priebe, C. G. Svedin, Sexual debut before the age of 14 leads to poorer psychosocial health and able commentary on the state of their own domestic law, allowing readers to compare both jurisprudential and technical differences in national treatment of difficult family law issues. Polish contributors provide careful analysis of the law and often provide specific suggestions for legislative reforms. Overall the book is a valuable contribution to all who care about Polish law and public policy.

\section{Marriage and Conflict-Solving Measures}

Part I of the book is devoted to the nature of marriage and the role of the law in identifying relationships encompassed within the legal definition of that relationship. Individual chapters summarize the current state of the law in the United States and Poland while identifying some of the ongoing debates or challenges in each country. Two additional chapters explore the nature of domestic violence in the United States and

risky behaviour in later life, „Acta Paediatrica” 2015, vol. 104, issue 1, pp. 91-100.

7 Addiction is considered a reasonable basis for divorce by $77 \%$ of Poles. D. Tułowiecki, Family as a Value in Contemporary Polish Society. Principles of the Christian Family in the Modern World. The $30^{\text {th }}$ anniversary of the „Familiaris Consortio", red. Z. Struzik, Warszawa 2012, pp. 177-213.

8 See K. Sitnik-Warchulska, B. Izydorczyk, Family Patterns and Suicidal...; J. Heitzman, M. Lew-Starowicz, M Pacholski, Z. Lew-Starowicz, Children Sexual Abuse in Poland - 257 Sexual Offenders against Minors, „Psychiatria Polska” 2014, vol. 48, issue 1, pp. 105-120 (reporting almost 30\% were of surveyed sex offenders were under influence of alcohol or another substance during the crime). 
Poland, while arguing that a proper understanding of marriage can contribute to substantial declines in such violence.

\subsection{The American Experience in Redefining Marriage}

In Judges Rewrite History and Law to Redefine Marriage, Professor Helen Alvare provides a brief legal history of the definition of marriage in the United States from the country's founding in 1776 through the U.S. Supreme Court's redefinition of marriage in same public goods of married couples - stabilization of sexual relationships, mutual support, and nurturing of children. While natural procreation remains impossible in same-sex unions, these couples argued that they were in no different position that other adoptive or step-parents in providing healthy and secure homes to children created through natural or artificial means. A second constitutional challenge was grounded in claims that exclusion of such couples from the state's definition of marriage violated substantive due process. ${ }^{12}$

\section{When marriage falters, family formation is stymied or warped.}

its 2014 opinion, Obergefell v. Hodge. ${ }^{9}$ For more than 200 years, the American people and courts accepted the legal definition of marriage as the union of one man and one woman. This consensus was so strong in 1879 that a unanimous Supreme Court rejected a claim that the practice of polygamy was constitutionally protected under the First Amendment's free exercise of religion clause. The Court rejected the claim based on its perception that polygamy, as a family structure, would undermine American constitutional norms of democratic governance. ${ }^{10}$

It was not until the 1990s that the American consensus began unraveling, largely through litigants' attempts to redefine marriage through the courts, rather than through the democratic process. ${ }^{11}$ The challenges were couched in constitutional language with claims that the historic and natural definition of marriage violated either equal protection because same-sex couples provided most, if not all, of the

9576 U.S. ___, 135 S.Ct. 2584 (2015).

10 Reynolds v. United States, 98 U.S. 145 (1878).

11 H. Alvare, Judges Rewrite History and Law to Redefine Marriage, (w:) red. G. Blicharz, Marriage, Children and Family: Modern Challenges and Comparative Law Perspective, Wydawnictwo Instytutu Wymiaru Sprawiedliwości 2019, pp. 13-32.
Unlike the Polish Constitution, the United States Constitution has no express protections for marriage, parents, or families. At the time of its adoption in 1788, the national constitution was seen primarily as a compact among sovereign and independent states for the purpose of defining and allocating powers between the national and state governments. ${ }^{13}$ Notwithstanding the debate and passage of a national bill of rights in 1791, individual rights such as speech, religious liberty, and due process were understood to be primarily the concern of state constitutions. ${ }^{14}$ Marriage, parentage, and family has little role in these discussions as

12 H. Alvare, Judges Rewrite History..., pp. 17-18.

13 See generally J. S. Sutton, 51 Imperfect Solutions: States and the Making of American Constitutional Law, Oxford University Press, Oxford 2018.

14 The original thirteen states were constitutional entities before the adoption of the federal constitution in 1787. Delaware, Maryland, New Hampshire, New Jersey, North Carolina, Pennsylvania, South Carolina, and Virginia all enacted constitutions in 1776. Georgia and New York wrote constitutions the following year, 1777. Massachusetts adopted its constitution in 1780. Only Connecticut and Rhode Island continued to function under their colonial charters until they replaced them with constitutions in 1818 and 1842 respectively. 
evidenced by their absence from state constitutions predating the federal constitution.

It was only with the emergence of the practice of polygamy in the mid-1800s in the United States that the definition of marriage became a matter of constitutional concern. As noted by Professor Alvare, the U.S. Supreme Court rejected the practice in Reynolds v. United States, ${ }^{15}$ observing, "there never has been a pretation, imposed a new gender-free definition of marriage on all fifty states.

While this history provides insight into one path to redefining marriage, given the differences in the constitutions of Poland and the United States, Polish readers may be more interested in Professor Alvare's description of the consequences of the Court's redefinition of marriage. Clashes over the religious liberty

\section{Unlike the Polish Constitution, the United} States Constitution has no express protections for marriage, parents, or families.

time in any State of the Union when polygamy has not been an offence against society." A few years later in Murphy v. Ramsey, the Court noted that "certainly no legislation can be supposed more wholesome and necessary in the founding of a free, self-governing commonwealth, fit to take rank as one of the coordinate states of the Union, than that which seeks to establish it on the basis of the idea of the family, as consisting in and springing from the union for life of one man and one woman in the holy estate of matrimony..."16 That opinion largely concluded the legal debate for the next century in the United States.

One hundred years later a new challenge emerged seeking to redefine marriage as the public union of any two adults. In the face of that challenge state after state recommitted itself to the historic definition of marriage as the union of one man and one woman. "Between 2003 and 2012, over 30 U.S. states passed laws defining marriage as the union of one man and one woman; and refusing to recognize as a "marriage" a same-sex marriage contracted in another state." Ultimately, however, the challengers prevailed, not by political persuasion but by judicial mandate when the Supreme Court, in the guise of constitutional inter-

1598 U.S. 145, 165 (1879).

16114 U.S. 15,45 (1885). of citizens who continue to adhere to the historic definition of marriage, and government confusion over the rights of children to know and be raised by their biological parents are just two of the damaging conflicts that have emerged from the U.S. Supreme Court's overruling of the political process. ${ }^{17}$

The religious liberty questions raised by redefining marriage are serious and severe. Yet as Professor Alvare notes, a recent U.S. Supreme Court decision, Masterpiece Cakeshop v. Colorado Civil Rights Commission, ${ }^{18}$ largely sidesteps these questions, ${ }^{19}$ instead focusing on the unconstitutionality of anti-religious bias by government officials administering anti-discrimination laws. While a valuable win for Christians and others who are deliberately targeted for their religious beliefs, the opinion leaves open the question of whether neutral enforcement of laws that require participation in same-sex ceremonies by all wedding vendors is con-

17 Professor Alvare provides a greatly expanded version of her arguments in her new book $\mathrm{H}$. Alvare, Putting Children's Interests First in US Family Law and Policy: With Power Comes Responsibility, Cambridge University Press, Cambridge 2017, https://www.cambridge.org/core/books/putting-childrens-interests-first-in-us-family-law-and-policy/8F8E7BDE74E7C7E43645A55DC83F05BE\#fndtn-information. 18138 S. Ct. 1719 (2018).

19 H. Alvare, Judges Rewrite History..., p. 24. 
stitutionally permissible. Such mandated participation is particularly troubling given a recent South African court mandating recognition of same-sex unions for ordination purposes by the Dutch Reform Church. ${ }^{20}$

\subsection{Polish Legal Recognition of Marriage}

Protection of the Institution of Marriage as a Union of a Woman and a Man by Dr. Tomasz Barszcz follows Professor Alvare's chapter with a thorough textual analysis of Polish law defining marriage. His treatment of the domestic constitution and international agreements of Poland will be invaluable to those seeking to understand why the American experience need not foreshadow the outcome of the present Polish debate on the nature and definition of marriage. He observes that the intent of existing legal provisions are clear, but provides concrete suggestions for avoiding any claims of ambiguity by proponents of polygamy and same-sex unions. Polish legislators and government officials charged with implementing and defending the law will gain a detailed understanding of how each word in the statutory scheme contributes to the conclusion that legal recognition of marriage is, and should remain, limited to only the union of one man and one woman.

\subsection{Communal Value of Traditional Marriage}

The discussion of the nature and definition of marriage is rounded out by Aude Mirkovic's chapter, The Social Dimension of Marriage We Should Discover Again. She recognizes the social necessity of an institution that promotes the creation and nurturing of children by their biological parents. Professor Alvare makes this point in her analysis of U.S. definition of marriage, but Dr. Mirkovic dives more deeply into the reasons for rewarding opposite-sex couples who undertake the public obligations of marriage.

She notes that, unlike same-sex couples, only the sexual union of a man and a woman can result in the creation of a new human being. From the moment of creation, each human being is vulnerable and needs the support and protection of others. During preg-

20 Gaum and Others v Van Rensburg NO and Others (40819/17) [2019] ZAGPPHC 52; [2019] 2 All SA 722 (GP) (8 March 2019) at http://www.saflii.org/za/cases/ZAGPPHC/2019/52.html. nancy, the mother shelters and nourishes the child within her body, often rendering herself physically or economically vulnerable during this period of intense dependency. The dual dependency of mother and child imposes responsibilities on the man who fathered the child, and marriage has emerged as the social structure to ensure men fulfill this responsibilities. ${ }^{21}$

Marriage recognizes and privileges stable long-term sexual unions between men and women who publicly commit to undertake the important work of forming a family through the creation and care of children. Property and inheritance rights, favorable tax treatment, and joint decisional authority over issues of mutual support and the care of offspring are just some of the ways societies have honored marriage over other social arrangements or sexual liaisons. Yet these privileges are quickly fading as governments increasingly fail to provide distinctive benefits to married couples.

In concluding his chapter, Dr. Mirkovic urges lawmakers to resist efforts to reduce marriage to that of other domestic arrangements. She warns that the well-being of children, their parents, and ultimately the larger society is undermined when marriage is treated as having no greater social utility than that of roommates or same-sex couples.

\subsection{Prevention of Domestic Violence}

Part I of Marriage, Children, and Family concludes with two articles addressing domestic violence and its relationship to marriage. Professor Helen Alvare provides a depressing, but useful, summary of the nature and extent of domestic violence in the United States. Based on government statistics, surveys, and expert analysis, she notes that women who cohabitate are far more likely to suffer abuse than married women. An underlying theme of the chapter is the state's limited capacity to provide meaningful remedies to all victims of domestic violence, but particularly those involved in non-marital relationship. Sadly, this capacity is even further diminished when society ignores the real differences existing between men and women, and instead substitutes a false quality based on the myth of sameness. Marriage, properly understood, has its foundation in commitment and care of others,

21 S. Girgis, R. T. Anderson, R. P. George, What is Marriage?... 
which in turn encourages collaboration in the place of conflict. This fact alone should induce government officials to promote marriage as the safest and best living situation for women and their children.

Dr. Tomasz Barszcz opens the final chapter of Part I with the provocative question, "what are the legal remedies that can be used to end violence in marriage without destroying it?" He provides the same sort of careful textual analysis of Polish laws governing domestic violence within marriage as he provided in his earlier chapter on laws defining marriage. In this case, however, he identifies several troubling gaps and ambiguities in the law. Among the most disturbing are the differences in the remedies available to wives seeking protection through civil law and those available to women who resort to the criminal law for help. His analysis suggests almost a perverse incentive to resort to criminal law using the full coercive power provide the sort of moral and psychological guidance that leads to authentic reform and restoration of the couple's relationship. That said, I look forward to reading future articles by Dr. Barszcz addressing whether law can end violence in marriage without destroying the marital relationship.

\section{Unwanted Sexualization of Children}

Part II of Marriage, Children, and Family examines the problem of unwanted sexualization of children, the harms that accompany such sexualization, and the challenges of legally deterring practices creating the problem. Authors examine legal attempts by the United States, Great Britain, Australia, Hungary and Poland to eliminate, or severely limit, such practices. Comparing these legal structures provides readers with some insights into the strengths and weaknesses of each nation's approach.

\section{Lawmakers should carefully note the brief section,} Sexual Materials in Schools, since instruction in "preparation for family life" is a required
part of the national curriculum in Poland.

of the state, instead of seeking protection under the civil law with its greater flexibility to accommodate individualized solutions. He also carefully notes the some of the barriers to practical implementation of the law's promises for assistance in obtaining shelter and counsel during periods of estrangement and danger. Again, this chapter should be mandatory reading for legislators and government offices involved in reform and enforcement of these laws.

My only disappointment with Dr. Barszcz's chapter is that he never effectively answers his opening question. No doubt, this is due to his careful attention and analysis to the detailed statutory scheme governing domestic violence, but I remain disappointed. I am skeptical that positive law can simultaneously protect husbands and wives from spousal violence, and
Professor Alvare opens Part II with a detailed review of United States laws aimed at regulating the portrayal of sex by, with, or to minors. Communal responses to sexual imagery and activities related to children range from treatment as sexual abuse and trafficking of a child to commercial rewards for production of apparel intended to emphasize the sexual potential of children and teens. The chapter provides a valuable history of the law's evolution, as well as developments driven by changing technology and social mores. ${ }^{22}$

22 Readers interested in somewhat dated, but excellent historical analysis of U.S. laws regulating sexual conduct will enjoy R. E. Rodes, On Law and Chastity, „Notre Dame Law Review” 2001, vol. 76, issue 2, pp. 643-740, https://scholarship.law. nd.edu/law_faculty_scholarship/240. 
Lawmakers should carefully note the brief section, Sexual Materials in Schools, since instruction in "preparation for family life" is a required part of the national curriculum in Poland. ${ }^{23}$ Similar to the U.S. experience, ${ }^{24}$ the Polish requirement initially was introduced "to educate young people about the anatomical and biological concepts of sexual life, as well as issues related to parenthood and family." 25 Activists, both domestically and internationally, have urged expanding the curriculum to include new definitions of family and questionable claims of healthy sexual conduct. ${ }^{26}$ Typically introduced as "comprehensive sexuality education," proponents claim that such curricular changes will reduce sexually transmitted infections, teen pregnancies, and violence against girls and women. Yet empirical evidence supporting these claims is conflicting, and should be critically examined prior to implementing curricular changes. ${ }^{27}$

For legislators and policy makers Professor Alvare's chapter provides a treasure trove of ideas about the various motivations and means that drive the sexualization of children in, as well as the U.S. government's wide-ranging, yet only modestly successful, attempts to protect children.

23 Regulation of the Minister of National Education from February $17^{\text {th }}$ 2012, Dz.U. 2012 poz. 300.

24 A brief history of American family life education as well as examples of objectionable content are contained in T. S. Collett, Government Schools, Parental Rights, and the Perversion of Catholic Morality, „Journal of Markets \& Morality” 2018, vol. 21, issue 1, pp. 95-115; University of St. Thomas (Minnesota) Legal Studies Research Paper No. 18-03, https://ssrn. com/abstract $=3112784$.

25 M. Woźniak, Sexuality education in Polish schools, „Przegląd Socjologiczny” 2015, vol. 64,issue 1, pp. 121-135.

26 Two examples of materials prepared by activists are the Universal Declaration of Sexual Rights, a product of International Planned Parenthood Federation, and the Yogakarta Principles, prepared at an international gathering of academics. These documents, often cited as authoritative, have no legal standing. See UN Commission on Human Refugees at https://www.refworld.org/docid/48244e602.html.

27 S. Gennarini, M. Orlandi, R. Oas, Seven Reasons to Reject „Comprehensive Sexuality Education”, https://c-fam.org/ briefing_paper/seven-reasons-reject-comprehensivesexuality-education.
Research from the American Psychological Association informs us that girls who internalize the messages of the hypersexualized pop culture tend to have more depression, anxiety, lower self-esteem, eating disorders, and risky sexual behavior. Moreover, girls are more at risk for rape, battery, and being trafficked in a society where pornography is normalized. While girls are not the major consumers of pornography, they suffer the consequences because they engage in sexual relationships with boys and men who have had their sexual templates shaped by mainstream online violent pornography. ${ }^{28}$

Ksenia Bakina's chapter presents an in-depth discuss of pornography's sexualizing effects on children, and attempts by the United Kingdom to limit access in the internet age. Acknowledging from the outset that pornography is not the sole, or perhaps even the primary means of sexualizing children, Ms. Bakina briefly describes "the 'pornification' of the UK culture and the encroachment of pornography in many spheres of everyday life." Gone are the days of licensed sex shops and topless females appearing weekly in a national tabloid. Today regulators are dealing with pervasive access to pornography via computers - whether desktop, laptop, tablet, or cell phone. The author reports that by the age of nine, 52 per cent of British children have a mobile phone by the age or 15 the number rises to $95 \%$. Contradictory evidence of parents' ability to effectively police access by their children leave public officials discouraged and unwilling to rely exclusively on parental supervision - and parents' do not want to be primarily responsible either.

This has led to legislative focus on the distributors of pornographic material. What will probably interest the reader most is Ms. Bakina's description of the age verification requirements for access to online video and pornography. Such a requirement would seem to be largely innocuous, and consistent with good

28 G. Dines, Growing Up With Porn: The Development and Societal Impact of Pornography on Children, „Dignity: A Journal on Sexual Exploitation and Violence" 2017, vol. 2, issue 3, pp. 1-9, https://digitalcommons.uri.edu/dignity/ $\operatorname{vol} 2 /$ iss $3 / 3$. 
business practices to ensure payment since the most common way to purchase access to pornography is through credit cards. Nevertheless, privacy experts are concerned that to prove legal compliance distributors would maintain records of identifying information. The chapter provides two tragic examples of unscrupulous people obtaining access to such records and blackmailing those identified. Critics also warn that the development of databases identifying sexual practices or preferences of citizens, if obtained by the government, could result in dystopian monitoring of the private lives of us all.

By the end of the chapter, I remain convinced that government has a role in protecting our young from pornography, but I confess to feeling unsettled and discouraged about law's ability to address what in the end may be more a matter of communal morality, than commercial activity.

In the third chapter of Part II Professor Filip Ciepły provides a thorough compendium of Polish criminal law protecting children from sexualization. He includes domestic statutes, annotations to cases and commentary explaining their proper interpretation, constitutional provisions, as well as international and regional agreements ratified by the Polish government. This compendium informs his brief comparison with British and Australian criminal laws on the same topic. The chapter concludes with specific suggestions for enhancing the protections afford by Polish law, as well as calling for the integration of provisions addressing sexual tourism. While perhaps too technical for the casual reader or lawyer practicing in other areas, this chapter will be of immense value to those charged with drafting and enforcing the law.

In chapter four László Detre introduces Hungarian law as a delicate balance between respecting constitutional protections of freedom of communication and protecting the freedom for minors from the negative effects of the unwanted sexualization. After introducing Hungarian cases applying the freedom of communication to varied means of communication, the author notes that public morality, which not specifically recognized in the Hungarian constitutional provision, is recognized in European Convention on Human Rights, and thus an integral part of Hungarian legal analysis.
Two key principles have emerged from cases dealing with sex-related communications: first, that prepublication censorship is strongly disfavored, subject only the strongest public justification; and second, that commercial communications or advertisements are provided a lower level of protection than other forms of communication. In 2010, the Hungarian Parliament enacted legislation to provide guidance to the press, the media, and advertisers regarding sexually motivated content. In each of these areas, the legislation relies for compliance upon the self-regulatory bodies of the media service providers, of the providers of complementary media services, of the publishers of press products, of the broadcasters and intermediary service providers. When self-regulation fails, the Media Council has regulatory authority to issue legally enforceable rulings. These rulings may include imposing a fine, requiring public notice of a transgression, or suspending operation for defined time. While not appealable within the council, the rulings are subject to judicial review.

Adam Szafrański provides the fifth and final chapter of Part II of the book. In concluding this section of the book Professor Szafrański provides a brief summary of Polish law on pornography in public spaces, then introduces the 2015 parliamentary draft resolution of 2015 calling on the Minister of Administration and Digitization to guarantee parents the right to the Internet free of pornography. The resolution was ultimately withdrawn due to a lack of enforceable regulations, but provides a starting point for lawmakers to begin addressing the distribution of pornography via internet.

While guardedly in favor of the regulation, Professor Szafrański notes the common concerns about censorship and regulation of extraterritorial activities by pornography distributors. He describes the British experience with parental controls, and the challenges to age-verification requirements. He appears confident that constitutional means of limiting minors' access to pornography exists given the state's interest in public morality and emerging evidence that access harms the mental and emotional health of minors, but warns than any restriction on rights of economic activity, speech, and privacy must be proportional to the harms suffered by children due to pornography. 


\section{Government Response to Addiction and Substance Abuse}

Part III of Marriage, Children, and Family is both the shortest, comprised of only three chapters, each with substantial descriptions of the various procedures used in civil or criminal commitment. The use of government power to deal with the problems of addiction and substance abuse is challenging given current understanding of individual autonomy and personal responsibility (or culpability), as well as the legitimacy, limits, and dangers of government coercion in matters of medical and psychological treatment. comparing Polish law to the German and Austrian approach. Unlike the prior chapter, the analysis is strictly statutory with less consideration of the overall jurisprudential aims of various approaches. While Krisztina Petra Gula provides helpful background to the reasons for varying approaches, Dr Hab. Joanna Długosz gives both detailed procedural insights for litigation arising from Polish law, and concrete suggestions for Polish legislators.

Filip Ciepły authors the final chapter of the book. Professor Cieply provides a short history of compulsory therapy before setting out the constitutional and

\section{This is a book to be read slowly and kept on the reference shelf for frequent reference by legislators and family law attorneys.}

Krisztina Petra Gula examines commitment proceedings from the competing aims of retribution and deterrence inherent in criminal law, and restoration or restraint at the heart of compulsory medical treatment. Culpability for a crime is largely dependent upon the mental state of the perpetrator. In this chapter the reader is introduced into various European countries' definition of insanity and mental illness. Based upon their definition, each country adopts either the framework of criminal law, its substantive, procedural, and executive branch or the medical and administrative laws of the state in dealing with a mentally impaired person. The English, German, and Polish approaches are described and compared to each other and to Hungarian law. The author concludes that some overlap in the two models is inevitable, but all approaches must guarantee that treatment must be available, and that the duration of restraint within the medical model be consistently evaluated to avoid unjust indefinite imprisonment.

Dr hab. Joanna Długosz's contribution to Part III analizes Polish law dealing with involuntary treatment of drug and alcohol addiction through the lens of international and regional agreements, as well as legal requirements of Polish law. He then provides an overview of compulsory treatment law in the United States, Great Britain, and Australia. His is description of the law is both thorough and readable.

Based on his survey of history, the law and the scant evidence of the success through compulsory treatment, Dr. Cieply concludes:

[I]t seems reasonable to return to the classic, personalistic concept of man as the basic assumption of social and legal institutions. The correction of disorders, improvement of behaviours or treatment of addictions on this basis cannot be guaranteed by means of legal instruments. Therapeutic and rehabilitative orientation of state coercion measures instrumentalizes and infantilizes the issue of liability in law and cannot be the basis for creating and applying the state coercion measures. No man should be treated as an object of interactions consisting in compulsory therapy or sociotechnical correction of character."

If readers read only one chapter in Part III of this book I would recommend Professor Cieply's chapter. 


\section{Conclusion}

This is a book to be read slowly and kept on the reference shelf for frequent reference by legislators and family law attorneys. Each of the three parts provides chapters on foreign law as well as chapters providing clear summaries of existing Polish law. This mix of chapters offers the reader not only a sound grounding in Polish law, but insights into how other nations address common questions surround the nature of marriage, the unwanted sexualization of children, and compulsory treatment due to addiction. As with any collection individual readers will find some chapters more helpful or interesting that others, but each chapter will provide new ideas to those who spend the time with this collection.

Paper was made possible thanks to the project „The Protection of Public Order - a Comparative Law Aspects" realized by The Center for Family Research of Nicolaus Copernicus University granted by Fundusz Sprawiedliwości of Ministry of Justice of the Republic of Poland

Artykuł powstał w ramach projektu „Ochrona Porządku Publicznego - wybrane aspekty prawnoporównawcze", który realizowany był przez Centrum Badań nad Rodziną Uniwersytetu im. Mikołaja Kopernika w Toruniu, w ramach grantu „Funduszu Sprawiedliwości”, Ministerstwa Sprawiedliwości Rzeczypospolitej Polskiej

\section{Bibliography}

Blicharz G. (ed.), Marriage, Children, and Family: Modern Challenges and Comparative Law Perspective, Wydawnictwo Instytutu Sprawiedliwości, Warszawa 2019.

Collet T. S., Government Schools, Parental Rights, ande the Perversion of Catholic Morality, „Journal of Markets \& Morality” 2018, vol. 21, issue 1, pp. 95-115.
Corvino J., Gallagher M., Debating Same Sex Marriage, Oxford University Press, Oxford 2012.

Dines G., Growing Up With Porn: The Development and Societal Impact of Pornography on Children, „Dignity: A Journal on sexual Exploitation and Violence" 2017, vol. 2, issue 3, pp. 1-9. Girgis S., Anderson T. R., George P. R., What is Marriage? Man and woman: A Defense, Encounter Books, 2012.

Heitzman J., Lew-Starowicz M., Pacholski M., Lew-Starowicz Z., Children Sexual Abuse in Poland - 257 Sexual Offenders against Minors, „Psychiatria Polska” 2014, vol. 48, issue 1, pp. 105-12-. Kastbom Å. A., Sydsjö G., Bladh M., Priebe G, Svedin G. C. Differences in sexual behawior, health, and history of child abuse among students who had and had not angaged in sexual activity by the age of 18 years: a cross sectional study, „Adolescent Health, Medicine and Therapeutics 2016, vol. 7, pp. 1-11.

Kastbom Å. A., Sydsjö G., Bladh M., Priebe G, Svedin C. G., Sexual debut before the age of 14 leads to poorer psychosocial health and risky behavior in later life, „Acta Paediatrica” 2015, vol. 104, issue 1, pp. 91-100.

Rodes R. E., On Law and Chastity, „Notre Dame Law Review” 2001, vol. 76, issue 2., pp. 643-740.

Sitnik-Warchulska K., Izydorczyk B., Family Patterns and Suicidal and Violent Behavior among Adolescent Girls - Genogram Analysis, „International Journal of Environmental Research and Public Health" 2018, vol. 15, issue 9, pp. 1-16.

Such-Pyrgiel M., Legal Changes Against the Family and Single People in Twenty First Century in Poland, „Annales Universitatis Apulensis. Series Jurisprudentia” 2014, vol. 17, pp. 148-156.

Svyrydenko D., Tułowiecki D., Family Policy of the State as a Response to Social Security Threats, „Future Human Image”, 2018, vol. 10, pp. 92-102.

Tułowiecki D., Family as a Value in Contemporary Polish Society. Principles of the Christian Family in the Modern World. The $30^{\text {th }}$ anniversaryof the „Familiaris Consortio”, red. Z. Struzik, Warszawa 2012, pp. 177-213.

Wax A., The Family Law Doctrine of Equivalence, „Michigan Law Review” 2009, vol. 107, issue 6, pp. 999-1017.

Woźniak M., Sexuality education in Polish schools, „Przegląd Socjologiczny” 2015, vol. 64, issue 1, pp. 121-135. 